\title{
Fraud control in offshore banking centres
}

\author{
by Ricardo M Alba
}

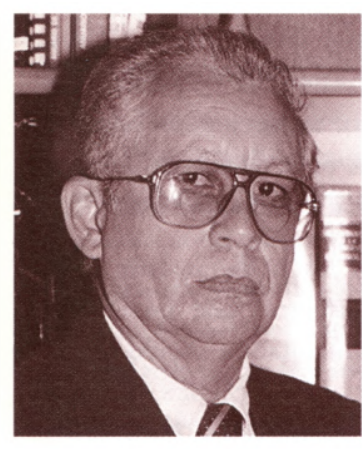

Ricardo M Alba

New measures to prevent financial crime in the offshore banking centres of Latin America and the Caribbean are helping to bring about more effective controls. Ricardo Alba of Panama welcomes the present trend towards closer international cooperation and greater vigilance.

A lthough not likely to be a specific policy regarding prevention policy and control of financial crime in the Caribbean and Latin American offshore centres, a genuine trend may be discerned. This article summarises the measures taken, which fall under the following categories.

\section{ACTION TAKEN BY GOVERNMENTS}

(1) The legal rules enacted by governments following the 1988 UN Convention against drugs and related crimes ('the Vienna Convention'), the 40 Recommendations of the Financial Action Task Force (FATF) and its Caribbean Financial Task Force (CFTAF) branch, and the Model Regulations of OAS/CICAD have increased the availability of legal definition and practical measures to combat fraud crimes, at least related to drugs crime, and other fraud as a subsequent outcome. Also, slowly but steadily, countries have been including fraud and other financial crimes in their laws on 'money laundering'.

(2) Adoption by countries of the region of the Basle Core Principles for Effective Supervision of Banks recommended by the Basle Committee on Banking Supervision enhances their engagement against fraud bankruptcy in the financial sector basic rules.

These Core Principles, or prudential regulations, which impose minimum standards for the various activities of financial institutions should also be implemented to ensure that the management of these institutions conduct their activities in an appropriate manner. The banking laws on prudential regulations should include provisions for the following:

- licensing of financial institutions;

- minimum levels of capital and capital adequacy criteria;

- regulation of share holdings;

- regulation and supervision of holding companies;

- inspection by and periodic reporting to the supervisory authority;

- restrictions on large exposures and related lending;

- fit and proper criteria for shareholders, directors and officers;

- classification criteria for shareholders, directors and officers;

- duties and responsibilities of directors;

- establishment of depositor protection mechanisms;

- audit requirements;

- winding up provisions.

Regional supervisors also need to have at their disposal a range of remedial and punitive measures to correct unsound banking practices.

In order to effectively combat money laundering, for example, and other financial crimes, it is also important for bank regulators to work closely with law enforcement agencies.

The Offshore Group of Banking Supervision has been particularly active in the promotion of the Core Principles amongst offshore centres. The Offshore Group was established following the First International Conference of Banking Supervisors held in London in 1979, when the Basle Committee on Banking Supervision ('the Basle Committee') decided to hold a meeting of banking supervisors representing offshore centres. One of the conditions of membership is a clear commitment to the principles of effective banking supervision cmbodied by the Basle Committec and it is likely that these conditions will soon include the Core Principles.

There is a temptation, at least in principle, for some offshore centres - or jurisdictions that wish to become offshore centres as a result of the economic benefits they see accruing to those centres - to seek deliberately to attract international banks to their territories by offering minimal supervisory standards. This is one of the activities which the Offshore Group actively seeks to guard against and it is welcome that one of the Core Principles spells out a policy of even standards. (Colin Powell, 'Cross Border Banking and the Core Principles for Effective Supervision', Caribbean Financial ActionTask Force FinanceTypology Exercise, Port of Spain, Trinidad, March 1998.) 
Mutual legal assistance treaties between countries, so far mostly aimed at the exchange of information, capture of criminals and seizure of illegal funds from drugs crimes, are part of the trend to include fraud and other financial crimes (e.g. tax evasion when it is directly related to drugs crimes).

Early warning information provided to financial institutions through Interpol, the Federal Bureau of Investigations (FBI), the Office of the Comptroller of the Currency (OCC) and other official organisations helps a great deal to prevent general patterns of financial fraud and to raise awareness about specific cases of such crimes. As an example, the OCC distributed 64 Alerts or New Releases in 1997. Five of them warned of 'unauthorised banking practice' in Vanuatu, Belize, Western Samoa, the Marshall Islands, Dubai and Madagascar.

\section{ACTION BY PRIVATE INSTITUTIONS}

(1) Correspondent banking relationships and the increasing globalisation of banks through acquisition and mergers with banks in Europe and North America helps to increase the standards of the financial system as a whole to prevent and control fraud.

(2) Banking associations perform an informative and educational role in improving the ability of banks to prevent financial crimes: the same is true of forensic investigation and consultancy services provided by law firms and auditors who offer their expertise to prevent and investigate securities fraud, health care fraud, check kiting schemes, loan fraud, fraudulent financial statement issues, insurance claims investigations, bank failures, due diligence investigations, asset misappropriations, embezzlement, fraudulent reporting of contract obligations, investor fraud in real estate partnerships, corporate compliance programs, directors' and officers' liability issues.

(3) The ICC Commercial Crime Bureau (CCB) was set up in January 1992. Its main objective is to act as a focal point for fraud prevention and to encourage better co-operation between commerce and law enforcement agencies in their fight against fraud. The bureau is aware of the paramount need for fraud prevention and continues its efforts in raising public awareness through publications, seminars and the mass media. The CCB maintains an extensive database on all aspects of commercial fraud.

(4) Last, but not least, offshore companies and informationrelated services provide an important source of warnings to customers in regard to legal rules and actual or potential fraud schemes. The following warning notice (taken from www.goldhaven.com website on the Internet) is an example of advice on tax cvasion given to customers by an offshore services company:

'Tax warning for US Citizens: US citizens are taxed on their taxable income from wherever it is derived, anywhere in the world. US citizens are also taxed on investments indirectly made through foreign trust and foreign corporations, including offshore trusts and IBCs. Thus, the fact that an offshore jurisdiction may have low or no taxes does not mean that if a US citizen does business there that he or she will enjoy only low or no taxes on the income made. There are simply NO income tax advantages, at all, for US citizens to use offshore structures, and anyone who tells you differently is probably telling you a falsehood. Any discussion we make of an offshore jurisdiction's tax laws should be construed only according to the foregoing warning.'

\section{INFLUENCE OF OTHER FINANCIAL CRIMES CONTROLS}

The ability of governments and financial institutions to prevent drugs money laundering, is being improved by the application of the 'know your customer' rules. Education and training for employees and customers should also be enhanced.

The 'know your client' rule provides a service to both the client and the institution adhering to it. By having full details of a client's personal and financial circumstances and investment objectives, the private banker is in a better position to determine the appropriateness of any account activity or transaction on behalf of their client, and to detect any attempt by a third party to gain access to funds on deposit or information about an account.

A diligent effort must be made to learn the essential and current financial and personal circumstances and investment objectives of each client. Relevant documentation should reflect information about any material changes to the client's status on an on-going basis. Most financial institutions have strict standards in place with respect to the opening of accounts and for ascertaining the identity of customers, beneficial owners and the source of funds deposited into an account.

Institutions should use due diligence to learn the essential facts relevant to a client. These include, as a minimum, age, net worth and earnings, banking knowledge, investment knowledge and investment objectives. The prudent banker must take the time to learn the essential facts relating to every transaction, instruction or order accepted, and ensure that each is within the bounds of good business practice. In addition, the banker must ensure that recommendations and advice given on an account are appropriate for the client and are in keeping with the client's banking, financial and investment objectives. Suitability should be based on information provided by the client in response to the institution's 'know your client' enquiries.

Awareness of these duties and adherence to these standards are particularly important when the banker is also acting as a custodian or trustee, or performs any other fiduciary role.

The legal obligation of banks and other financial institutions to report 'suspicious transactions' to financial intelligence units has created a flow of information mainly related to the intention of fraud rather than drugs money laundering, which has been of practical use in avoiding such abuses of financial services by criminals

\section{INTERNATIONAL BANKING CENTRE OF PANAMA}

Panama has established an offshore service infrastructure supporting the international economy such as free circulation of the US dollar, since independence from Colombia in 1903, incorporating laws based on the law of Delaware dating back to 1927, extraterritoriality taxation principles since the 1960s, and the International Banking Centre since 1970. Banks in Panama are required to have a physical presence, i.e. employees, premises and a licence. There are no 'brass plate' banks.

Besides the legal rules established in the Criminal Code there are no specific procedures recommended or adopted by banks, 
supervisory or police authorities in order to prevent financial fraud. Most action against this sort of crime is derived from the following sources:

\section{(1) Legal rules for the prevention of drugs money laundering.}

In particular, the implementation by banks of measures based on the new 'know your customer' approach has improved their awareness regarding financial fraud and its detection. These include the following:

- Reporting 'suspicious transactions' to a Financial Analysis Unit (in operation since 1996) has generated a number of reports on fraud.

- The Mutual Legal Assistance Treaty on criminal matters with the USA includes financial fraud as one of the crimes subject to exchange of information, prosecution of criminals and seizure of illegal funds.

- Systematic reporting of transactions by companies operating in the Colon Free International Trade world results in higher standards to control fraud in foreign trade.

- The Panamanian Association of Banks (Apabancos) has reached an agreement amongst members to establish a common set of customer information requirements for opening accounts and providing banking services to customers from Panama and abroad

- Acting attorneys and resident agents of companies incorporated in Panama are obliged by law to identify the beneficial owners of such companies when so required by authorities.

\section{(2) Adoption of the Core Principles of Banking Supervision}

A new Banking Law fully adopting the 25 Basle Core Principles of Effective Banking Supervision was enacted in February 1998. The principles in regard to lending to owners and economic groups tied to the bank will be of utmost usefulness in preventing loan bankruptcy fraud.

\section{(3) Other actions}

The following additional actions have been taken Panama:

- In 1996 Panama sponsored and hosted the International Conference on Financial Fraud, which provided a platform for ample discussion of types and cases of financial fraud.

- An agreement on information and technical training in financial fraud was established in May 1998 between the Panamanian Association of Banks and the Technical Judiciary Police (PTJ), which had recently been established for the investigation of financial crimes. The agreement involves a more open supply of information on fraud from the banks to the police, and training in fraud detection for members of the force.

- In August 1998, the Panamaian Government issued a new type of passport containing technical features that makes more difficult the use of a counterfeit document as a 'second passport'.

\section{DEGREES OF CONTROL}

It is useful to bear in mind the different approaches adopted by offshore centres regarding the control applied to economic crimes, not only in Latin America and the Caribbean but also in other parts of the world. These can be summarised as follows.

\section{Strict control}

Firm policies and measures have been adopted by governments and financial institutions to prevent economic crimes for local and/or offshore customers. Countries concerned are: France, Hong Kong, Netherlands, Portugal, Singapore, Switzerland, UK, US.

\section{Moderate control}

Polices and measures have been adopted by governments and financial institutions to prevent drugs money laundering, but not to other economic crimes. Countries concerned are: Aruba, Bahamas, Barbados, Bermuda, British Virgin Islands, Cayman Islands, Costa Rica, Cyprus, Gibraltar, Grenada, Guernsey, Isle of Man, Jersey, Licchtenstein, Luxembourg, Malta, Monaco, Netherlands, Antilles, Panama, Paraguay, Taiwan, Uruguay, Yugoslavia.

\section{Poor control}

Almost total absence of policies and measures to prevent economic crimes. Countries concerned are: Anguilla, Antigua, Bahrain, Belize, Cook Islands, Dominica, Macau, Malaysia, Marshall Islands, Mauritius, Montserrat, Nauru, Niue, Samoa, Slovakia, Seychelles, Sri Lanka, St Kitts \& Nevis, St Vincent/Grenadines, Thailand, Turks \& Caicos, Vanuatu.

(Information taken from United States Department of State, Bureau for International Narcotics and Law Enforcement Affairs, 'International Narcotics Control Strategy Report', March 1998.)

\section{CONCLUSION}

The following conclusions may be drawn:

(1) There does not seem to be any factual basis for the assertion that offshore centres favour financial fraud, nor that certain types of fraud may be more closely associated with offshore centres.

(2) Most of the efforts presently made in offshore and onshore centres to prevent and control financial fraud are driven by the more active and committed actions underway to prevent and control drugs money laundering which are under strong pressure from the international community.

(3) A great part of the effort is carried out by private sector organisations, thus overcoming the political, technical and economic constraints and shortcomings of governments.

(4) An almost universal pattern of response to financial fraud is that banks are reluctant to inform about fraud of which they are victims, and the judiciary system finds difficulties in trying cases of fraud.

(5) Bank loan bankruptcy fraud is the most damaging financial crime in the Latin America region, as well as in other parts of the world, in terms of loss of savings and the high social cost of bank recovery.

(6) To enact legal rules against financial crimes, especially bank loan bankruptcy fraud, is good but not enough. Criminals must be sent to jail, their assets seized and a systematic implementation of these legal rules must be put into practice.

(7) Policies for controlling abuse are adopted by major offshore centres as a result of national concerns and pressure from 
the international community. That is why some centres promote their high regulatory standards while others do not do so to the same degree. The implementation of such policies requires a balance between keeping business moving forward and avoiding financial crimes.

(8) Legal rules need not only to be enacted but also enforced. Particular qualities are needed by banking regulators and other regulatory bodies in order to perform this role successfully and would normally include:

- professional competence;

- professional qualifications in the area that he or she is regulating;

- social confidence and ability to mix, with an outwardlooking and easy disposition;

- experience - generally on both sides of the divide (as knowledge of the pressures of the marketplace helps in making better judgments);

- respect within the industry that they regulate;

- non-political approach all costs;

- fairness and integrity (regulators must be scrupulously fair and have unimpeachable integrity; it must be absolutely clear as to what is acceptable and what is not rules must be universal and allow no favouritism;

- discretion
(Taken from Charles Cain, 'Regulation standards', Offshore Investment, December/January 1994, p. 3.)

(9) International regulators also need to work together more closely. It is when regulators co-operate with their counterparts in another jurisdiction in order to obtain the necessary exchange of information in respect of a financial institution from another jurisdiction applying to operate a financial services business, or one which is already operating in both jurisdictions, that they are able to extend their information base and thereby do their regulatory job more efficiently. If the Bank of England had been better informed about the problems of Barings in Singapore, for example, there would probably have been a very different outcome.

\section{Ricardo M Alba}

President, Agrica-Lex, Panama

This article is based on a lecture delivered at the Sixteenth Symposium on Economic Crime, Jesus College, Cambridge, in September 1998.

\section{OFFSHORE CENTRES ${ }^{(1)}$}

\section{Countries offering 'offshore' services within their jurisdiction}

Germany (Frankfurt), Ireland (Dublin), Italy (Trieste Offshore Centre), Morocco (Tangiers), Taiwan, Thailand, United Kingdom (City of London), United States of America (Colorado, Delaware, Miami, New York).

\section{Island Centres}

$\begin{array}{llll}\text { Americas } & \text { Asia/Pacific } & \text { Europe } & \text { Other } \\ \text { Anguilla } & \text { Cook Islands } & \text { Cyprus* } & \text { Bahrain* } \\ \text { Antigua } & \text { Hong Kong* } & \text { Guernsey* } & \text { Mauritius* } \\ \text { Aruba* } & \text { Labuan } & \text { Isle of Man* } & \text { Seychelles } \\ \text { Bahamas* } & \text { Macau } & \text { Madeira } & \text { Malta* } \\ \text { Barbados* } & \text { Marianas } & \text { San Marino } \\ \text { Bermuda* } & \text { Marshall Islands } & \\ \text { Cayman Islands* } & \text { Naura } & \\ \text { Montserrat } & \text { Niue } & \\ \text { Netherlands Antilles } & \text { Singapore* } & \\ \text { Nevis } & \text { Vanuatu* } & \\ \text { St Kitts } & \text { West Samoa } & \\ \text { St Lucia } & & \\ \text { St Vincent } & & \\ \text { Turks and Caicos } & & \\ \text { Virgin Islands } & & \end{array}$

\section{Mainland Centres}

Andorra, Belize, Costa Rica, Dubai, Gibraltar*, Lebanon*, Liechtenstein, Luxembourg, Monaco, Panama*, Switzerland.

* Members of the Offshore Group of Banking Supervisors

(1) This list of offshore centres is taken from the speech given by Colin Powell, Chairman of the Offshore Group of Banking Supervisors, 'Caribbean Action Task Force International Finance - Typology Exercise', Port of Spain, Trinidad, March 1998. 